Черній В. О., аспірант Держсавний університет інфраструктури та технологій м. Київ, Україна

DOI: https://doi.org/10.30525/978-9934-26-068-1-13

\title{
УПРАВЛІННЯ \\ СТОЛИЧНИМ ГРОМАДСЬКИМ ТРАНСПОРТОМ: ПРОБЛЕМИ ТА ШЛЯХИ ЇХ ВИРІШЕННЯ
}

Громадський транспорт виступає ключовим фактором впливу на розвиток соціально-економічних систем на макро- (країна), мезо- (регіон) та мікрорівнях (окреме місто або село). Особливого значення муніципальний транспорт набуває для соціальноекономічного розвитку столичних регіонів та столиць країн світу. У той же час великі розміри, розгалужена мережа та пасажиропотік у столицях роблять управління громадським транспортом базисом для забезпечення стійкого соціально-економічного розвитку столичного регіону.

Управління столичним громадським транспортом стикається зі значною кількістю проблем, що потребує їх ідентифікації та розробки шляхів вирішення у контексті формування сприятливого середовища для економічного, соціального та екологічного розвитку столиці і регіону.

Відзначаємо значний науковий інтерес до розвитку столичного громадського транспорту, ідентифікації проблем його управління та розробки шляхів оптимізації управління в сучасних умовах трансформації соціально-економічних систем столиць світу. Акцентуємо увагу на наукових дослідженнях наступних вчених: Є.Н. Водовозова та О.Ю. Палант [1]; Д.А. Шатірішвілі [2]; І.С. Клименко, С.В. Кривошєєвої та О.К. Кривенко [3]; О.М. Зборовської та О.Л. Дивінець [4]; Дж. Буткевичуса та Л.П. Лінгаітіса [5]; А.Дж.Л. Пеіхсото Нето, М.Л. Галвеса, О.Ф. Ліми Джуніора, Д. Такли [6]. Однак, процеси, що постійно відбуваються в межах розвитку столичного громадського 
транспорту, вимагають продовження досліджень відносно виявлення та усунення проблем його управління.

У більшості країн світу столиця та столичний регіон $\epsilon$ найбільш заселеними, а також великими за територіальними розмірами, що призводить до формування значних пасажиропотоків, переважна частина 3 яких обслуговується громадським транспортом. В цих умовах, важливим $\epsilon$ ефективне управління столичним громадським транспортом, що стикається 3 наступними головними проблемами:

1. Складність поєднання та конкуренція між приватним i муніципальним громадським транспортом. Значні пасажиропотоки вимагають запровадження альтернативних схем перевезень громадським транспортом (метро, електротранспорт, автобуси та ін.), що породжує конкуренцію за пасажирів, у тому числі конкурентну боротьбу між приватними та муніципальними перевізниками. Конкуренція призводить до витіснення частини перевізників 3 ринку, що $\epsilon$ соціальною $і$ транспортною проблемою для столиці.

2. Логістика пасажиропотоків. Наявність місць проживання та місць праці і необхідність постійного переміщення між ними мешканців столиці, а також швидка забудова столиці i столичного регіону призводять до постійних логістичних проблем, які збільшують час переміщення пасажирів громадським транспортом у «години-пік», а також формують райони столиці та столичного регіону у які складно дістатися.

3. Забезпечення комфорту пасажирів та якості їх обслуговування. Недостатність інформації відносно часу очікування на зупинках громадського транспорту, низький комфорт у «години пік», проблеми 3 оплатою за проїзд, час, що витрачається на транспортні пробки формує незадоволення споживачів послуг столичного громадського транспорту.

4. Навантаження на екологічну систему столиці та столичного регіону. Проблема має дві складові: значна кількість міського транспорту, що використовує бензин або дизельне пальне, завдає значної шкоди екології; незадоволення якістю та вартістю послуг 
міського транспорту зі сторони пасажирів призводить до зростання використання ними особистих автомобілів, що збільшує шкоду для екології міста та регіону.

5. Децентралізація управління столичним міським транспортом, коли окремі перевізники формують власні стратегії розвитку та забезпечення транспортними послугами мешканців столиці. Наведене викликає постійні конфлікти інтересів та від'ємну синергію у взаємовідносинах всіх учасників процесу управління столичним міським транспортом.

6. Підготовка і перепідготовка персоналу у сфері муніципального транспорту столиці. Швидкі зміни у транспортній сфері, у тому числі у сфері перевезень пасажирів, вимагають відповідної підготовки і перепідготовки персоналу муніципальних органів влади, а також перевізників. Однак, брак коштів та часу, а також недостатне розуміння важливості підвищення кваліфікації призводять до не бажання муніципалітетів, підприємств у сфері перевезень пасажирів та окремих робітників цієї сфери приділяти увагу професійній підготовці і перепідготовці.

Наведена проблематика вимагає пошуку шляхів іiі вирішення, де ключовими, у сучасних умовах розвитку громадського транспорту, повинно бути:

1. Підвищення якості аналітичної роботи відносно пасажирських перевезень у столиці та столичному регіоні, що дозволить виділити головні «вузькі» місця та розробити заходи їх усунення. При цьому, необхідним є проводити аналіз за такими напрямами: дослідження роботи всіх видів пасажирського міського транспорту в цілому та окремо по кожному виду транспорту; аналіз пасажиропотоків на маршрутах; дослідження часу, що витрачають пасажири на поїздки у періоди різного завантаження міського транспорту; аналіз витрат міської влади, перевізників та пасажирів; екологічне навантаження в цілому та від кожного виду громадського транспорту; конкуренція в цілому та між окремими видами громадського транспорту. 
2. Активізація впровадження сучасних інформаційних технологій у межах управління пасажиропотоками, формування систем оплати за проїзд, підвищення якості надання послуг пасажирам.

3. Утворення відповідних громадських майданчиків та проблемних груп 3 представників сфери муніципальних перевезень для пошуку проблем і розробки єдиних алгоритмів їх вирішення, а також формування позитивних синергетичних ефектів взаємодії.

4. Реформування системи підготовки та перепідготовки персоналу у сфері громадського транспорту з залученням Вищих учбових закладів, а також професійних консультантів і тренерів.

5. Дослідження та імплементація закордонного досвіду, а також залучення закордонних консультантів для ідентифікації проблем і розробки шляхів їх вирішення в межах управління столичним громадським транспортом.

6. Формування централізованих органів управління столичним міським транспортом 3 забезпеченням представництва в них, як представників муніципальних органів влади, так і підприємств, що надають послуги з перевезення пасажирів.

7. Реформування системи столичного громадського транспорту у контексті зниження екологічного навантаження і використання безпечних для екології видів транспорту. При цьому, вважаємо доцільними зробити акцент на розробку та запровадження стимулів заміни екологічно небезпечних транспортних засобів у перевізників, зменшення використання особистих автомобілів, розвиток мереж громадського альтернативного транспорту (велосипеди; електричні велосипеди, скутери, самокати).

Відзначаємо важливість ідентифікації та усунення проблем управління столичним громадським транспортом у контексті забезпечення розвитку столиці і столичного регіону. Вважаємо доречним у подальших дослідженнях сконцентрувати увагу на використанні інформаційних технологій у вирішенні управлінської проблематики столичного муніципального транспорту. 


\section{Література:}

1. Водовозов С.Н., Палант О.Ю. Критерії оптимізації міського транспортного сполучення м. Києва. Інновачійна економіка: Економіка та конкурентоспроможність підприємств. 2019. № 3-4. С. 80-85.

2. Шатірішвілі Д.А. Функціонування міського громадського транспорту крізь призму концепції сталого розвитку. Державне управління: теорія та практика. 2017. № 1. С. 76-83.

3. Клименко І.С., Кривошєєва С.В., Кривенко О.К. Проблеми та перспективи розвитку ринку пасажирських автомобільних перевезень в Україні. Вчені записки ТНУ імені В. І. Вернадського. Серія: Економіка і управління. 2019. № 6. С. 21-26.

4. Зборовська О.М., Дивінець О.Л. Розвиток підприємств міського електричного транспорту України: проблеми та перспективи. Інвестииії: практика та досвід. 2016. № 24. С. 24-27.

5. Butkevičius J., Lingaitis L.P. The problems of urban public transport and their solution trends. WIT Transactions on The Built Environment. 2005. № 77. P. 85-93.

6. Peixoto Neto A.G.L., Galves M.L., Lima Júnior O.F., Tacla D. Challenges of urban transport problems and city logistics: Sao Paulo city center case. WIT Transactions on The Built Environment. 2008. № 101. P. 133-142. 